Arhe XVIII, 36/2021

UDK 111.1

81 '37

$2-264$

DOI https://doi.org/10.19090/arhe.2021.36.73-97

Originalni naučni rad

Original Scientific Article

АНА МИЉЕВИЋ ${ }^{1}$

Универзитет у Новом Саду, Филозофски факултет

\title{
ОДРЕЪЕЊА ИЗВОРНОГ ЗНАЧЕЊА PHYSIS-А КАО ПРОБЛЕМ ОНТОЛОГИЈЕ
}

Сажетак: Питање изворног значења фи́бı-а поставља се зарад наше властите онтолошке позиционираности, зарад савремености у којој и којом битно јесмо. Овај рад стога испитује семантику корена фúбı-а, хеленску

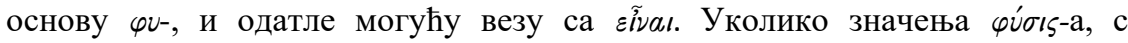
обзиром на етимолошку основу речи, леже између раста, подстицања на pacm и бивствовања, поставља се питање раслојавања значења у његовој употреби у песништву. У раду се испитује дата вишезначност кроз однос

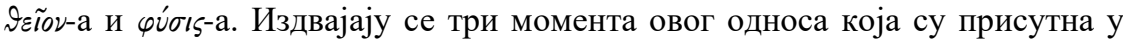
митском мишљењу: козмо-теогонијски, логосно-виталистички и етосновредносни. Теза је да се са ових хриди митског чи́бıৎ може сагледати у свом изворном значењу као (з)бивање којим биће јесте. Теза се испитује на примеру значења чúбı-а у Хомеровој Одисеји.

Кључне речи: physis, онтологија, митологија, семантика, Хомер

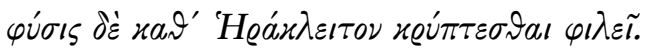

DK22 B123

Из обзорја Хераклитове мисли израња упитаност над

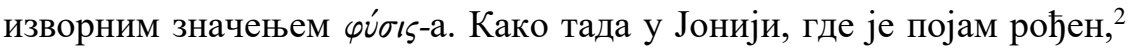

\footnotetext{
${ }^{1}$ E-mail адреса ауторке: anamiljevic@ff.uns.ac.rs

2 Најранији забележени појам чv́бı-а налазимо управо у Хераклитовим фрагментима. О значењу идиома чіл⿻і̃ + у јонском дијалекту и могућој персонификацији „природе“ у DK22 В123 видети код Graham, D. W.,
} 
тако и данас, „модернима“, измиче оно шта је чи́бı према свом битном одређењу. На који год начин питали, а модерни питају другачије, рекло би се спољашње, у последња два века доксографски, историјски, културолошки, лексички еtс., већ спрам тог упитаног проналазе да значење фúбı-а на датој разини није потпуно, слуте у њему нешто недоречено, наиме, да фи́бı при себи нешто још скрива. И сами затајимо оно што у овом појму слутимо. ${ }^{3}$ Јер оно, зашто питамо за хеленски појам чи́бı-а, шта је сврха нашег обраћања античкој епохи, јесте готово извесно, али најчешће прећутано. Наиме, ми питамо зарад нас самих, зарад наше властите онтолошке позиционираности, зарад савремености у којој и којом битно јесмо. Стојећи пред понором небића, ми савремени питамо о хеленском поимању фúбı-а. Тако и једино тако наше питање јесте из саме ствари. У захтеву за објективношћу при испитивању појма фи́бı-а, апоретичност лежи у томе што се исходиште хеленског разумевања фи́бı-а појављује као савременост, из које се потом пита о проблему његовог изворног одређења. Наш задатак овде није и не може бити изналажење еупорије у захтеву за објективношћу, већ осветљавање дијалектике појма чv́бı-а, којом се појам обнавља и питано опетује. ${ }^{4}$

\section{ПОРЕКЛО РЕЧИ PHYSIS}

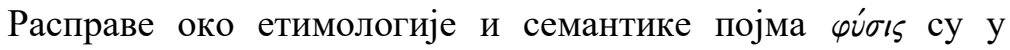
последњем веку веома бучне. Почеле су, чини се, са Барнетовим делом Рана грчка филозоија и ставом да чи́бı у V веку п.н. ере

\footnotetext{
„Does Nature Love to Hide? Heraclitus B123 DK“, in: Classical Philology, 98, 2003, pp. 175-179.

3 Хеленски глагол кеи́ $\tau \omega$ којег проналазимо у наведеном Хераклитовом фрагменту, може значити већ према својим облицима (med.) при себи нешто скривати, или (akt. tranz.) у пренесеном смислу затајити, nрећутати. Видети у: Gorski, O., Majnarić, N., Grčko-hrvatski ili srpski rječnik, Školska knjiga, Zagreb, 1983., str. 241.

${ }^{4}$ Наиме, као бесконачно поновљено питање како је мишљено у Z књизи Аристотелове Метафизике (Met. Z 1028b 2-5).
} 
означава оно што је у промени стално и непропадљиво, „од чега је свет сачињен“"5, а против чега је устао Хејдел у свом раду Пє $і$

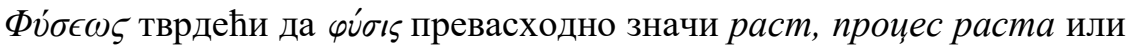
юегов резултат 6 . Аутори који су у наредним деценијама заузели, ако ништа друго а оно у главним обрисима, једну или другу страну, проширили су њихову аргументацију.

Према већини истраживача етимолошко порекло именице

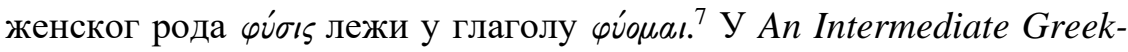
English Lexicon-у Лидел-Скота се за основу фи́бı-а узима презент индикатив актива овог глагола који гласи $\varphi \dot{v} \omega,{ }^{8}$ дакле, са кратким вокалом и чини се углавном прелазног значења у употреби у Хомеровим еповима. Према Мајнарићу и Горском значење глагола $\varphi v ́ \omega$ као транзитивног глагола се креће од родити до производити, учинити нешто да расте, а у примеру из Илијаде (Il. 6, 149) ${ }^{9}$ као

${ }^{5}$ Barnet, Dž., Rana grčka filozofija, prev. B. Gligorić, Zavod za udžbenike i nastavna sredstva, Beograd, 2004, str. 20. Група аутора који у мањој или већиј мери стоје на страни Барнета и његовог тумачења фúбı-а као бића или штавише бивства, придружују се још Поленц, Лавџој, Кирк, Гатри, Холверада, и у само начелно, у главним цртама: Лебедев, јер заузима став контра Барнета поготово када је реч о Пармениду, а слично Гатрију; Жмуд код Питагороваца као све што доспева у бивствовање према поретку.

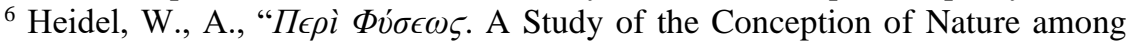
the Pre-Socratics", in Proceedings of the American Academy of Arts and Sciences, 45, 1910. Бирдсли, Вудбриџ, делом Патцер, Хајниман, Жмуд (код Емпедокла и Парменида) слажу се са Хејделом да чv́бı првенствено означава постанак, рађање и раст, дакле да има условно процесуално значење.

7 Штавише и Барнет истиче да никада није довео у сумњу понуђену етимолошку основу. (Barnet, Dž., Rana grčka filozofija, str.425.)

${ }^{8}$ Liddell, H. G., Scott, R. An Intermediate Greek-English Lexicon. Преузето са сајта:

http://www.perseus.tufts.edu/hopper/text?doc=Perseus\%3Atext\%3A1999.04.00 $58 \% 3$ Aentry $\% 3$ Dfu $\% 2$ Fsis

${ }^{9}$ Истичемо да ово није честа употреба, али је треба нагласити. Стихови Il.

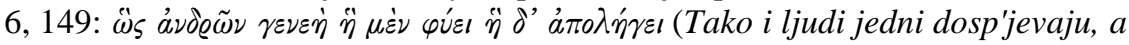

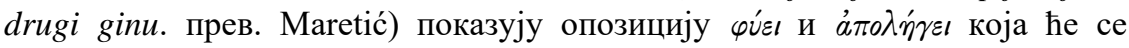
понављати и у пресократској филозофији, напрочито код Парменида и у првим стиховима Емпедоклове поеме Фvбixà. 
непрелазан може значити постајати, расти или потјецати. ${ }^{10}$ Проналазимо га у старини једнако као и код трагичара нпр. Еурипида $^{11}$ или у Софокловом Eduny (у 436. стиху) и Антигони (у стиху 647), те у многим другим примерима, па отуда и бројна значења овог глагола које Лидел-Скот наводе, а која ћемо ми сврстати у два основна: ${ }^{12}$

1. Са основним значењем „производити, произносити“ (eng. bring forth, produce, put forth) од ког глагол фúw транзитивно, у презенту, футуру или аористу има изведену семантику која упућује на узроковање развоја, те тако значи ,родити, створити, изазвати, породити“ (eng. beget, engender) у Еурипидовим Феничанкама у 869. стиху или Хелени у 87. стиху, затим „,развој појединаца/јединки спрам раста његових делова“" (eng. ...of individuals in reference to the growth of parts of themselves) као код Херодота у 104. реду осмог поглавља, код ког такође лежи и метафоричко значење „произвести високо мишљење о себи“" (eng. get glory or to form a high opinion of oneself) у 5. поглављу 91. реда, а које је употребио и Софокле у Антигони на горе поменутом месту;

2. Са значењем ,расти, ницати, напредовати “ (eng. grow, wax, spring up, forth). За биљни свет, и особе најчешће у аористу са значењем „бити по/рођен“ (eng. to be begotten, born) у Есхиловом Окованом Прометеју 27. стиху, затим значење „постати“ (eng.

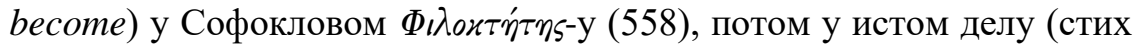
88.) као и Антигони (888) стоји употреба у смислу „бити обликован или предиспозициониран од стране природе да се дела на савим одређен начин“" (eng. to be formed or disposed by nature to do so and so), док је у Еурипидовој Медејu (у 928. стиху) смисао глагола „бити по природи склон“ (eng. is by nature prone).

${ }^{10}$ Gorski, O., Majnarić, N., Grčko-hrvatski ili srpski rječnik, Školska knjiga, Zagreb, 1983., str. 449.

${ }^{11}$ Euripides, Báx๔aı, 651.

12 Видети у: Liddell, H. G., Scott, R. An Intermediate Greek-English Lexicon. Преузето са сајта:

http://www.perseus.tufts.edu/hopper/text?doc=Perseus\%3Atext\%3A1999.04.00 $57 \% 3$ Aentry $\% 3 \mathrm{Dfu} \% 2 \mathrm{Fw}$ 
Не само у етимолошком смислу, већ семантички глагол

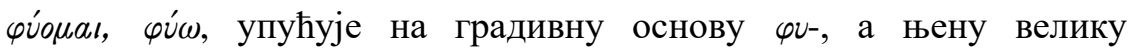
продуктивност и бројне изведенице показао је Фриск у свом Griechische ethymologische Wörterbuch, где поред основних значења глагола $\varphi \dot{v} о \mu \iota^{13}$ наводи и из глагола изведене именице међу којима

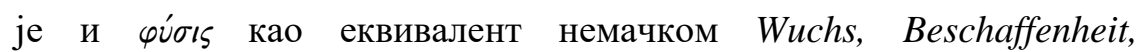
Abstammung, Natur, Wesen. Према Фриску, присутне форме глагола

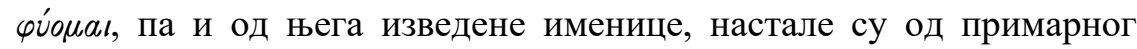
непрелазног облика аориста $\varphi \tilde{v} \nu a \iota, ~ \check{\varepsilon} \varphi \tilde{v} \nu$ укључујући и веома старе облике перфекта. Сходно томе и изведеницу чv́бı би требало разумети кроз овај облик, посебно ако тражимо еквивалент за хеленску основу $\varphi v-$ у индо-европском корену $b h \bar{u}-$, који носи значење бити, постати, али и потицати на развај. Фриск тврди да:

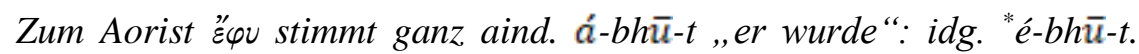
Dazu noch aksl. Aor. 2. u. 3. sg. by, alit. bu, lat. fui (alat. fui) usw. ${ }^{14}$ To указује да у творбеном смислу за читав низ именица изведених од глагола чv́ouaı може да се повуче паралела у групи индо-европских језика, од којих су за наш рад значајне две: прва је поменута латинска основа перфекта $f \bar{u}$ - глагола бити, а друга старословенски аорист бы 2. и 3. лица једнине. Оба примера показују да индоевропски корен чува етимолошку, а видећемо и семантичку, сродност иv́øљ-а са групом апстрактних именица, а које су, када је реч о српском језику, произашле из корена би-. Многе од њих припадају нашој филозофској и теолошкој терминологији као нпр. биће, бивање, бивствујуће, бит, бивствовање, али и јестање, јестаство, суштина еtс. При том је важно истаћи да су се сва рачвања из индо-европског у посебне облике појединачних језика

13 Према Фриску, непрелазна значења овог глагола која често стоје уз

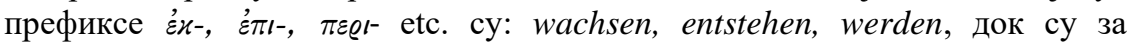
прелазни облик понуђене немачке речи: wachsen lassen, erzeugen, hervorbringen. За даљи семантички развој интресантни су посебно значења глагола у перфекту и аористу која Фриск преводи са von Natur geschaffen, beschaffen sein, da sein. (Frisk, H. Griechische ethymologische Wörterbuch, Band II, Heidelberg, 1970, S. 1052.)

${ }^{14}$ Ibid., S. 1054. 
према Фриску развијала упоредо, а независно једна од других, јер то додатно, упућује на семантичку паралелу између ч́́бı и наведене групе термина. ${ }^{15}$ Стога, Барнетово инсистирање на томе да је хеленска основа чv- еквивалент енглеског be и да нема у сваком смислу семантику коју је носио глагол чи́оаı у непрелазном смислу, дакле са дугим вокалом у значењу расти, треба разумети из контекста дате аргументације. ${ }^{16}$ Кирк се изгледа слаже са Барнетом у погледу значења глагола чv́oual, иако истиче да Барнет греши када чv́бı одређује као тварно почело (енг. staff). Наиме, он сматра да је расти (енг. grow) изведено значење овог глагола и да

15 Важно запажање Фриска следи једнакости које постоје у групи индоевропских језика: "Die Nomina steuern mehrere Gleichungen bei, die aber wegen der abweichenden Bedeutungen in mehereren Fällen eher als Parallelbildungen denn als Vertreter indogermanischer Grundwörter zu betrachten sind: $\varphi \tilde{u} \mu a$ „Gewächs, Geschwulst“ = aind. bhüma „Erde, Welt, Wesen“, alb. bimë „Pflanze“ (Mann Lang. 26.386) (срп. биље, прим. А. М.);

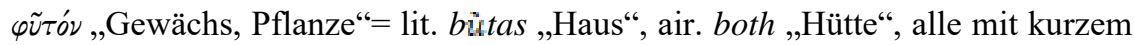
ǔ gegenüber den langvokalischen aind. bhūtếm n. „Wesen, Geschöpf, die vergangene Zeit“, slav., z. B. russ. byt „Wesen, Lebensart“; $\varphi$ v́øı „Wuchs, Beschaffenheit, Natur usw.“: aind. bhüti-, bhûti- „Wohnlergehen, Wohlfahrt, Kraft, Reichtum“" (vgl. Porzig Satzinhalte 333f.)“ Ibid. S. 1053, 1054. Именице дају неколико једначина, али их због различитих значења у неколико случајева треба сматрати паралелним творевинама, а не представницама индо-европских основних речи: фи̃на 'Gewächs, Geschwulst' = aind. bhüma n. 'земьа, свет, бивство', alb. ьітё 'биька' (Mann Lang. 26, 386); өо̃тóv 'биље, биљке' = lit. bùtas 'кyћa', air. both 'јазбина', све са кратким й насупрот дугом самогласнику aind. bhūtám $n$. 'бивство, створење, прочло време', слав., нпр. руски 'бивство, начин

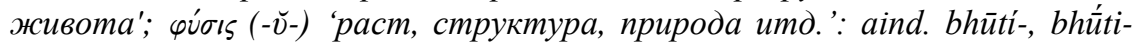
'благодат, благостање, снага, богатсво' (упор. садржај реченице Porzig 333 f.). (прев. аут.). Стога, Фемић-Касапис добро примећује да коренска сродност хеленског $\varphi v \sigma \varsigma$-а и словенског инфинитива büti у семантичком смислу значи да „све оно што бива, што јесте, што постоји, тим својим постојањем саопштава да у самој ствари расте, развија се.“ Фемић-

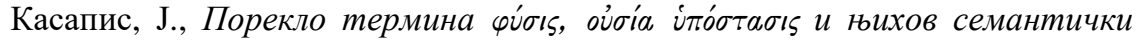
развој од најранијих помена до ирквених отаиа, ПБФ, Београд, 2010, стр. 10 .

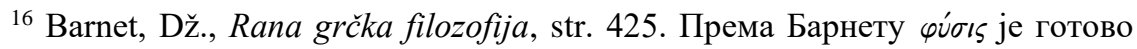
еквивалентан а̇øxं́-у. 
The root $\varphi v$ - simply implies existence, and the broad general sense of $\varphi v$ oıs, from which all specialized sense are derived, is essence or nature, the way a thing is made and, what is at times connected with this, the way it normally behaves. ${ }^{17}$

При том треба имати на уму да је највероватније на делу одсуство диференције значења унутар појма фи́бı-а, јер су за Талеса, каже Харди, Werden und Sein noch begrifflich zusammen и то првенствено као $\varphi \dot{\sigma} \iota^{18}$, упркос корену $\varphi$ - из ког је именица настала или управо стога.

Поменуту разлику у пореклу и значењу изведеница, а отуда

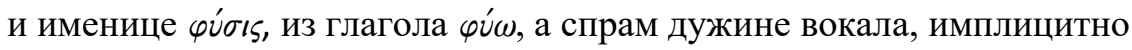
даје и Аристотел у појмовнику $\Delta$ књиге Метафизике. Аристотел наиме, прво примећује да је један од начина говора о чv́бı-у, говор у смислу постанка онога што расте (раслина) упућујући на дуг вокал у изговору речи чи́бı. У коментару Ладановог превода овог одељка Радин каже да је етимолошка основа речи чv́бı, глагол $\varphi \cup ́ \varepsilon \sigma \curvearrowright a \iota$ чији облици дају дуг вокал $v^{19}$ а чини се да Аристотел

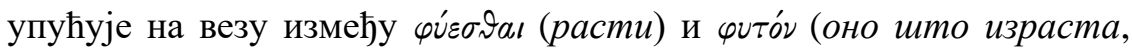

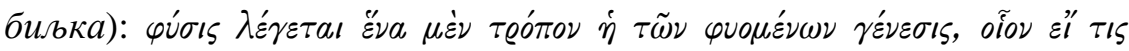

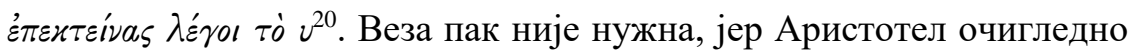
мисли да је за јасност и доследност у овом разумевању чи́бı-а потребна измена саме речи, као кад би сама реч фи́бı била изговорена са дугим вокалом. Присутна суздржаност у одређењу

${ }^{17}$ Kirk, Heraclitus. The Cosmic Fragments, Cambridge University Press, 1954, p. 228. „Корен чv- једноставно имплицира постојање, а широк општи смисао фvбı-а, одакле произилази сваки посебан смисао, јесте бит или природа, начин на који је ствар направљена и, оно значење које се са тим повремено повезује, начин уобичајеног понашања.“ (прев. аут.)

${ }^{18}$ Hardy, E., Der Begriff der Physis in der Griechischen Philosophie, Erster Teil, Weidmannsche Buchhandlung, Berlin, 1884, S.14. Постанак $u$ биствовање (су) појмовно још заједно.(прев. аут.)

${ }^{19}$ Aristotel, Metafizika, prev. Ladan, T., Globus, Zagreb, 1988, str. 112.

${ }^{20}$ Arist. Met. $\Delta$ 1014b 15-16. Преузето са сајта:

http://www.perseus.tufts.edu/hopper/text?doc=Perseus\%3atext\%3a1999.01.005 1 


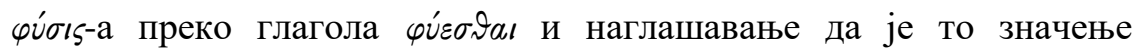
условљено могућом етимологијом, показује да оно није потпуно јасно и подразумевано значење у хеленском свету, у коме је због промене фонемских структура у језику коренски основ речи често био магловит и непрепознатљив. ${ }^{21}$ И према Лавџоју је како етимолошка повезаност, о којој је реч, тако и она семнатичка из ње изведена, могућа тек као секундарна:

... there is no safe inference from the meaning of $\varphi v$ oual to that of $\varphi v i \delta$, even where they happen to occur near one another in the same writer. The prevailing usage of qúpaı kept relatively close to the literal sense of 'to be born,' 'to be originated'; while by far the most frequent usage of $\varphi v \sigma ı$ in all classes of writers of all periods is in the highly developed sense which I have mentioned, - a sense developed out of a secondary meaning of yúoual, 'to be of such and such a sort by birth,' or 'innately'. ${ }^{22}$

На крају, чини се да ни сама етимолошка веза између $и \dot{\varepsilon} \sigma ح a \iota$

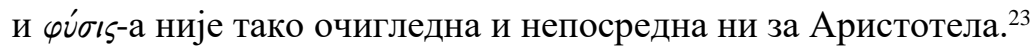

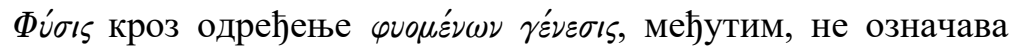
тек етимолошку везу између Аристотел на овом месту у Метафизици имплицитно упућује. Наиме, ствар стоји другачије са семантичким односом чv́бı-а и

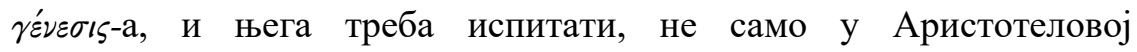
филозофији, већ и у префилозофском контексту разумевања фи́бıљ-а.

21 Steinthal, H., Geschichte der Sprachwissenschaft bei den Griechen und Römer, mit besonderer Rücksicht auf die Logik, Ferd. Dümmler`s Verlagsbuchhandlung, Berlin, 1883, S.24-36.

${ }^{22}$ Lovejoy, A. "The Meaning of $\Phi v \sigma ı$ in the Greek Physiologers", in: The Philosophical Review, 18, 1909, p. 375. „...не постоји сигуран пут од

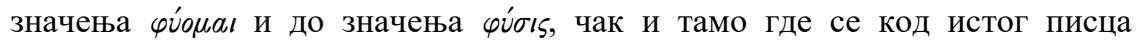
случајно употребљавају један уз други. Преовлађујућа употреба чи́онаı дата је релативно близу смисла 'бити рођен', 'настао'; док је најчешће коришћена употреба чv́бı-а код свих класичних писаца у свим периодима у високо развијеном смислу који сам већ поменуо, - смислу који је произашао из секундарног значења ф́́oual, ‘бити такве и такве (сасвим одређене) карактеристике по рођењу', или “урођен””. (прев. ауто.)

${ }^{23}$ Barnet, Dž., Rana grčka filozofija, str. 427; 


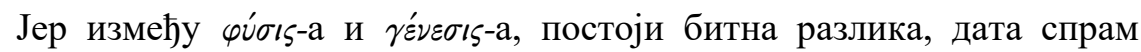
самосвојствености бића које се рађа или постаје, тј. с обзором на

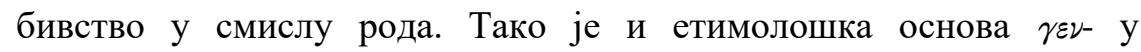
хеленском језику, како је то Патцер показао, везана за род

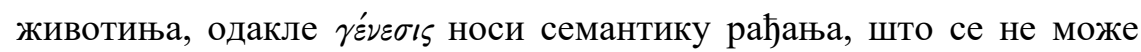
према њему тврдити за корен $\varphi$ - који изворно упућује на биље: Die Pflanze ist dementsprechend der gesuchte Urbereich der Wurzel $\varphi$ - und das Hervorbringen oder Wachsen die in dieser Wurze angesprochene Urerscheinung. ${ }^{24}$ Фúбı према томе не може да значи исто што и

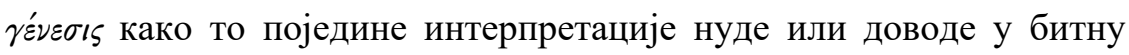

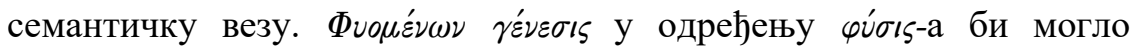
значити бивање бића рађањем, бивање бића које рађајући се узраста до пуноће свога битисања. ${ }^{25}$

С друге стране, могући разлог за Аристотелову суздржаност када је реч о етимолошкој основи $и \dot{\sigma} \iota \varsigma$-а проналазимо у хеленском

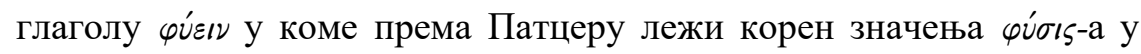
смислу резултата раста и развоја, али не и у смислу самог процеса

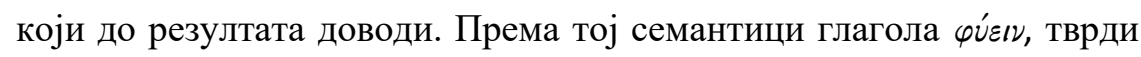
Патцер, и чv́бı носи семантику немачког Sein (бивствовање). Појачавању тог значења доприноси и наставак - $\sigma$, који чува градивну везу са ті eĩvaı. ${ }^{26}$ Интересантно је да за Холверду сама

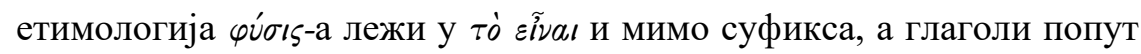

${ }^{24}$ Patzer H., Physis: Grundlegung zu einer Geschichte des Wortes, Steiner, Wiesbaden, 1993, S. 10. Сасвим је опречног мишљења Хејдел према коме се чv́бı у свом основном значењу раста подједнако односи на раст и

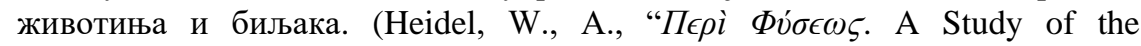
Conception of Nature among the Pre-Socratics", p. 98.)

25 Ово је, наравно, тек изведена и с обзиром на целину Аристотеловог појмовног корпуса могућа интерпретација датог места у Метафизиции, јер упућује и на процес и на његово усврховљење у довршености (крају/резултату) и први је мисаони корак који води ка појмовном пару

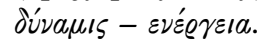

26 Фриск наводи да је творба забележеног новог облика аориста чи̃бal,

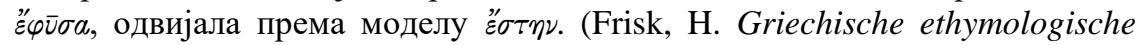
Wörterbuch, Band II, Heidelberg, 1970, S.1052) О суфиксу -бı видети више у

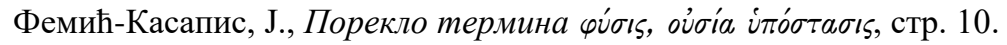




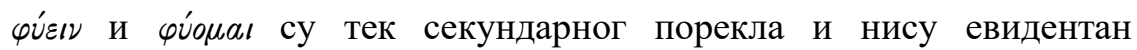
етимолошки корен $\varphi \dot{\sigma} \iota \varsigma-\mathrm{a} .{ }^{27}$

Из наведеног се очитује да постоје, како међу класичним филолозима тако и међу историчарима филозофије, не само неслагања око порекла и значења речи өи́бı, већ да постоји спор и

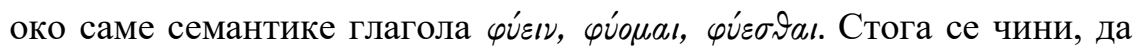
се суочавамо са бројним и неразмрсивим апоријама, уколико

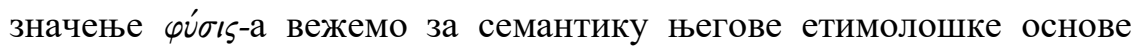

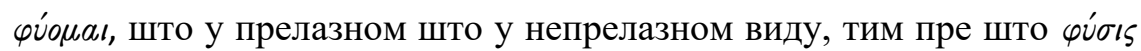
у свом распону значења има шири обим од онога што нам се понуђеном етимологијом намеће. Треба, међутим, нагласити да тешкоћа у коју смо запали није садржана у самој лексици, већ у нашој навикнутости да мислимо у категоријама које не припадају хеленском дискурсу, а када је реч о хеленском поимању чv́бı-а, то пре свега значи, да апорија којом смо сапети при покушају његовог

27 У полемици са Бридслијем и Патцером, а у уводу своје дисертације, Холверда каже: „Quod ad dispositionem attinet: in perpendendis locis quos collegi,magis atque magis miratus sum quod identidem idque quidem diversissime adhibita vox $\varphi v ́ \sigma ı \varsigma$ verbo 'esse' respondet. Sic paulatim inductus

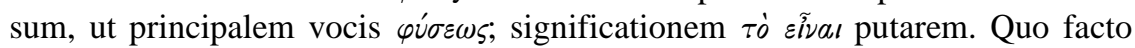
mox sponte se obtulit divisio tripartita. Verbum enim eĩal, cum copulative tum

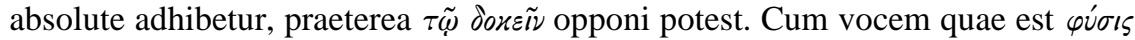
in easdem tres partes se findere appareret, his singulis deinceps singula capita tribui. Nonnullas tamen significationes huic significationi principali subiungi

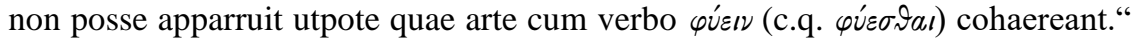
Holwerda, D., Commentatio de vocis quae est $\Phi Y \Sigma I \Sigma$ VI atque usu praesertim in graecitate Aristotele anteriore, Groningen, 1955, 1.7. „Што се тиче диспозиције: промишљајући места (делове текста, прим. аут.) која сам прикупио, изнова сам се чудио колико реч чv́бı и на како све различите начине одговара речи „бити“. Тако сам временом био подстакнут главном

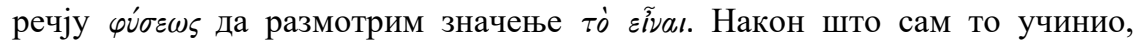
троделна подела се наметнула сама од себе. Јер реч ві̃ бı било у копулативној или апсолутној употреби такође, може бити антитеза $\tau \tilde{\varphi}$

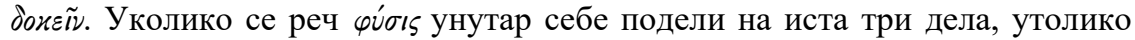
постоји паралела у додељивању свакој целини (значења) одговарајућег дела. Испоставило се да се главном значењу не могу доделити нека

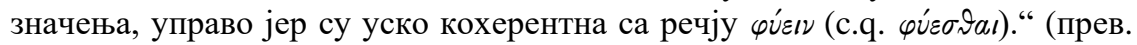
аут.) 
разумевања лежи у нашем опетовању о истозначности чv́бı-а и природе у нововековном смислу. Та привидна истозначност је последица низа метафизичких редукција, које је мишљење баштинило вековима.

У Уводу у Метафизику Хајдегер наглашавајући да наш истински однос према стварима присуствује (постаје и јесте) у језику, поставаља питање шта је истинско значење хеленског

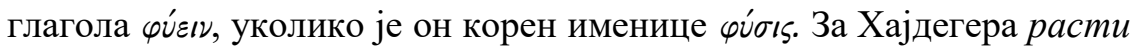
(nem. wachsen) означава појавност/присуство бивања, али не у смислу у ком субјекат опажа на неком појединачном објекту оно што се као ново показује кроз промену, раст и развој неке ствари, а која стоји у мноштву других феномена. Фи́бı одатле није укупност природне промене спрам које се ми на спољашњи начин односимо.

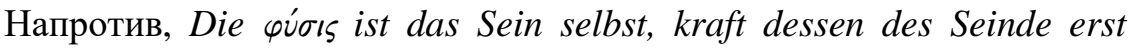
beobachtbar wird und bleibt. ${ }^{28}$ Речју, на основу $\varphi \dot{\sigma ı \varsigma-a ~ к а о ~}$

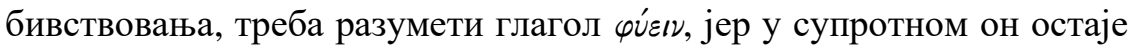
за наше мишљење неприступачан и лишен свог изворног смисла.

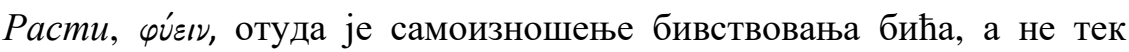
појавна промена на стварима или начин у којем се појединачно биће на спољашњи начин субјекту даје у опажају.

Из хеленског одношења спрам бивствовања, из њиховог искуства света, произилази именовање чv́бı-а као бивствовања, кроз који се потом у мишљењу пројављује само бивање бића бићем.

Die Griechen haben nicht erst an der Naturvorgängen erfahren, was

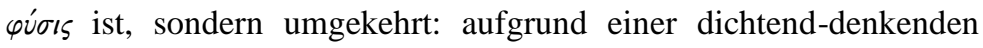

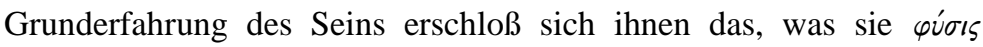
nennen mußten. ${ }^{29}$

28 Heidegger, M., Einführung in die Metaphysik, Vittorio Klostermann, Frankfurt am Main, 1983., S.17. „Фv́бı је бивствовање саิмо, дејством којег биће тек постаје и остаје опажљиво.“ (прев. аут.)

${ }^{29}$ Heidegger, M., Einführung in die Metaphysik, S. 17. („Грци нису тек искушавали шта је чúбı кроз природне процесе, већ обрнуто: на основу песничко-мисаоног искуства бивствовања за них се отворило оно што су морали да назову/именују чи́бı५.“ прев. аут.) 
Уз претпоставку да семантика глагола фи́оль заиста указује на изворно одређење $\varphi$ б́ı- $a$, Хајдегерово разматрање представља

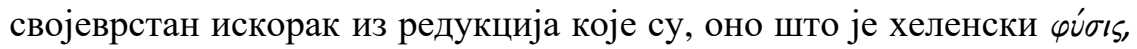
довеле до подразумеваног контекста природе. У том смислу, разумети сам глагол из онога што је означено као могуће одређење појма не представља догматски пут мишљења, већ дијалошки моменат као захтев да се чује оно што саопштава хеленска епоха. У складу са тим захтевом, преостаје нам да се упутимо у поетско-

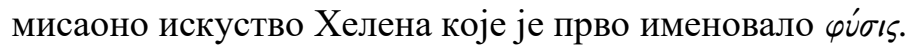

\section{MYTHOS И ОБРИСИ МОГУЋЕ СЕМАНТИКЕ PHYSIS-A}

Предањска основа на којој почива хеленски свет према

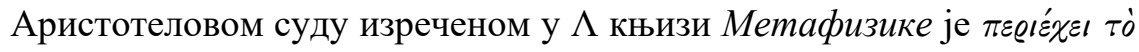

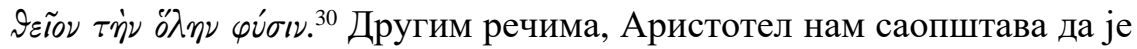
наслеђем „древних“ према коме божанско обухвата цео чv́бı, изграђена хеленска митологија и обичајност, њихово мисаоно искуство света, које је уткано у песништво. Али како у песништву

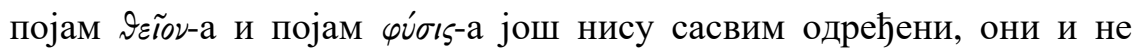
могу да имају општост која је одлика филозофског мишљења и не треба их схватати у апсолутном смислу. Њихово се значење тек наслућује кроз опевано збивање у коме хеленски јунак вођен божанским наумом и сопственим фи́бı-ом тка обичајност. Песник сведочи и једно и друго, али никада као опште, као целину. Тога је свестан и Аристотел када на истом месту каже да је на предању „древних“, а на корист светине, изграђен Олимп антропоморфних богова, и то зарад одржања обичајности и закона. Наслеђе

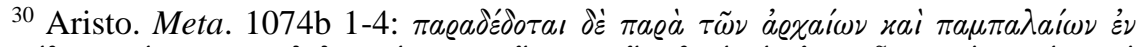

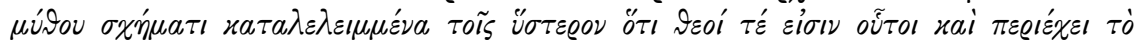

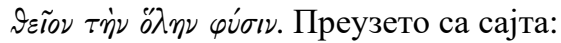
http://www.perseus.tufts.edu/hopper/text?doc=Perseus\%3atext\%3a1999.01.005 1

(„Drevni i |prastari /ljudi/ preneli su u obliku priče docnijim naraštajima predanja da su nebeska tela bogovi i da to božansko obuhvata celokupnu prirodu.“ Aristotel, Metafizika, prev. S. Blagojević, str. 433.)
} 
„прастарих“ ипак није тек полазиште ових, већ управља сваким

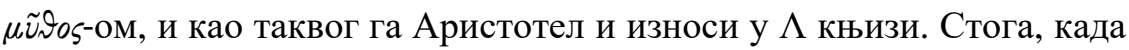
кажемо да је за разумевање појма чv́бı -а као темељног појма хеленске филозофије из ког извиру сви други појмови неопходан увид у хеленску обичајност, пре свега мислимо на нераскидивост,

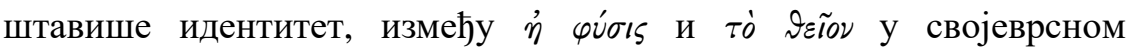
Stimmung-у хеленског човека.

Очаран величином и лепотом живота, епски јунак са дивљењем и чуђењем посматра пројављивање овог органског јединства божанског и $\varphi v$ бı--а које се догађа пред његовим очима. ${ }^{31}$ И управо је ова одлика хеленског духа, моменат који повезује

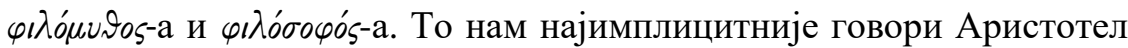
на самом почетку Метафизике у 982b 17-19: Сматра се да онај који поставља питања и који се чуди не зна (зато је љубитељ мита филозоф на неки начин, јер мит се састоји од чудесног)... ${ }^{32}$ Јасно је да није реч о томе да је чv́бı једноставно заменио Олимп, појам

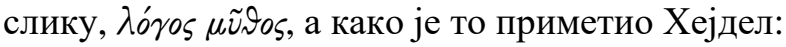

... in the world of Homeric thought every event was regarded as due to the activity of the gods, and that, as the conception of Nature replaced that of the gods as a basis of explanation, yúrı was conceived as the source of the manifold activities of the world. The phenomena of life, cosmic and microcosmic, seeming to occur spontaneously and without external cause and direction, naturally engrossed the attention of the philosopher and might well make it appear possible to dispense with a special cause of motion. ${ }^{33}$

\footnotetext{
31 Упркос томе што је оно дато у представном смислу и што је готово немогуће успоставити диференцију међу њима (или управо због тога),

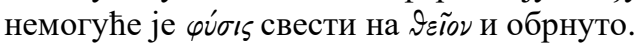

32 Аристотел, Метафизика, прев. С. Благојевић, стр. 7

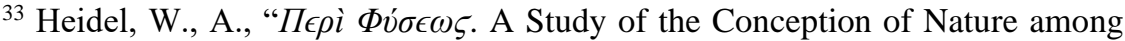
the Pre-Socratics”, p. 88, p 105. „У свету Хомерове мисли сваки догађај је сматран последицом активности богова, и то, како је концепција Природе замењивала концепцију богова као основ разјашњења, чи́бı је замишљен као извор многоструких активности света. Животни феномени, козмички и микрокозмички, који се чине спонтани и без спољашњих узрока и
} 


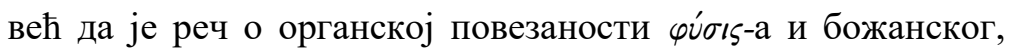
којом је хеленски дух исткао свој однос према „феномену живота“, а који је исказивао поетским говором. Иако Хејдел с правом тврди да хеленско поимање догађања како у микро- тако и у макрокосмосу, а који су сви одреда повезани са животношћу и њеном манифестацијом кроз снагу, покрет, раст и развој, ипак се не можемо сложити са тим да је

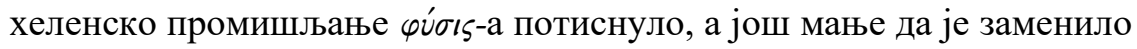
божански свет Олимпа. Поетски израз којим су се служили први филозофи и његово упадљиво одступање од употребног говора показује да a common picture of the nature of the Universe, of living creatures, and of divinity was shared by a surprising number of Greek philosophical and religious thinkers of the 6th and early 5th centuries B.C. ${ }^{34}$ И без обзира да ли ова заједничка одлика митотворног и филозофског начина мишљења долази из опажања сталне промене и кретања у козмолошком, физиолошком, метеоролошком и физичком смислу, или свести о властитој повесности и пролазности, у њој се очитава потрага за узроком и почелом бивања

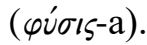

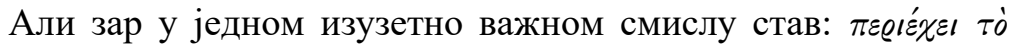

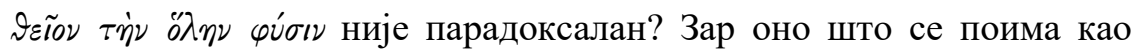

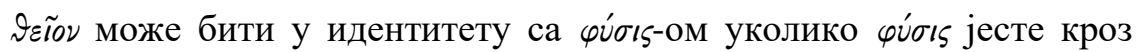
постанак, раст, развој и пропадање, кретање и промену? Зар основна одлика શะіол-а није вечност, непропадљивост, сталност? Зар питање пред нама не лежи у основи запитаности младог Платона; зар не лежи у покушајима дијалектичког разрешења датог парадокса у његовим позним дијалозима; зар питање није већ

усмеравања, природно су заокупили пажњу филозофа и чинили су могућим да се одвоје од посебног узрока кретања.“ (прев. аут.)

34 Gutrie, W. K. C., „The Presocratic World-Picture“ in: The Harvard Theological Review, 45, 1952, pp. 87-104: „...заједничку слику природе универзума, живих створења и божанског је делио изненађујуће велики број грчких филозофа и религиозних мислилаца 6. и раног 5. века п.н.е.“ (прев. аут.) 
порођено у филозофији Парменида, који своју мисао изражава у стиху богатом митолошким сликама?

Али упитаност и појмовно уобличавање парадокса органског јединства શ⿻ĩo-a и хеленску филозофију само потврђују истинитост Аристотелове тврдње. Другим речима, апоретичност овог јединства је присутна у самој ствари, али је свест о њој потоња. За хеленски начин мишљења парадоксалност је начин по коме све бива, она је истина догађања живота, света, човека.

Из приложеног се наслућује шта би могло да буде значење

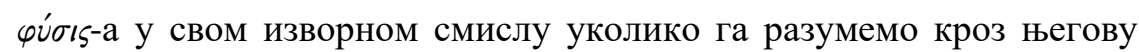

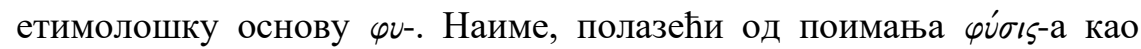
неодвојивог од поимања ح $\varepsilon \tilde{i} о \nu$-а, упућени смо на испитивање начина и домета хеленског искуства божанског. Како је, међутим, наш примарни интерес расветљавање појма чv́бı-а, а како хеленска мисао није развила систематску и јединствену теологију, у истраживању треба сагледати три битна момента митског која отварају врата за разумевање чúбı-а у филозофском дискурсу. Они се у митологији појављују појединачно попут хридовитих представа и у битном смислу покушај њиховог систематског повезивања би био својеврсно духовно насиље, урушавање смисла ког собом носе. Можемо их одредити, дакле, само с обзиром на њих саме и према ономе што са њих као таквих у даљини сагледавамо.

1. Први моменат $\mu \tilde{u}$ Ооร-а је кроз литературу већ обилно показан као козмо-теогонијски простор у коме је постанак схваћен на начин временског почетка (aеx’́) из ког извире филозофско разумевање почела (аехй) и слога (бтоххвіо $)$.

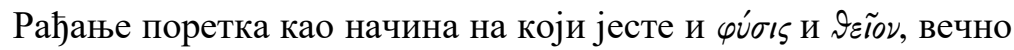

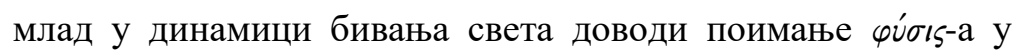

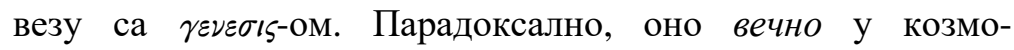
теогонијским представама постаје, рађа се, извире, временује у поретку, али не стари, не пропада, не умире.

2. Друга хрид митског, логосно-виталистичка, сагледава феномен живота и снаге као при-сутност божанства у 
догађању. Дакле, дата је, не више у претходном козмотеогонијском смислу свеукупности и динамике поретка света, већ као животна снага у појединачном, која је а) узрок промене, обрта, динамике сасвим одређеног догађаја, а којом се парадоксално б) сабира смисао догађања уопште. У литератури најчешће обрађивана кроз подручје „психолошког“ (Geist-Seele), она је подручје узрока и сагледавања смисла бивања бића које фи́бь у филозофском

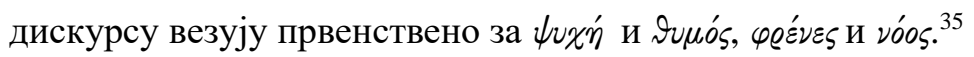

3. Трећа хрид, етосно-вредносна, јесте свет смртника који погледом добацује до божанског поретка и који начином на који јесте у свету може бити са-учесник у њему. Та могућност је отворена тек изврсношћу чина појединца у догађању, чина којим се смртник обесмрћује и показује

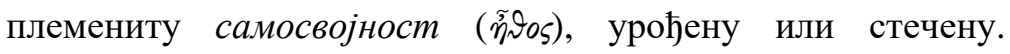
Херојски ஜ๊̃os изграђује хеленску обичајност чиме је постављен као највиша вредност. У самосвојности као битносној одлици бића открива се чи́бı првенствено у

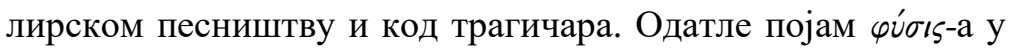
филозофском промишљању стоји у спрези са самосвојношћу бића, а изведено са бивством (ớó́a).

Тек кроз ове моменте митолошког можемо да наслутимо читаво семантичко богатство чv́бı-а, диференцијације унутар његовог поимања, нивое онтологизације, редукције које су потом уследиле, и на крају наш појам природе, као само једно, изведено и чини се узгредно значење појма $\varphi \dot{\sigma}$ $\varsigma-$-а. ${ }^{36}$ И да ствар о којој

${ }^{35}$ Видети у: Miljević, A. „Određenje životne snage u Homerovim epovima”, u: Godišnjak Filozofskog fakulteta u Novom Sadu, 42, 2017., 47-58.

${ }^{36}$ Посебна тешкоћа је то што семантика $\varphi \dot{v} \iota \varsigma$-а која се ослања на хеленско поимање божанског није у литератури посматрана из саме ствари, већ

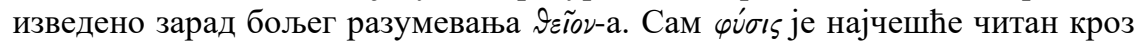
значење аехи́-а као твари како то чини Барнет и они који заузимају њему сличну позицију, а треба нагласити да Гатри и Јегер чине изузетке. Видети y: Guthrie, W. K. C, „The Presocratic World-Picture”, и y: Jeger, Teologija 
говоримо не би остала тек слутња, наредни редови ће бити

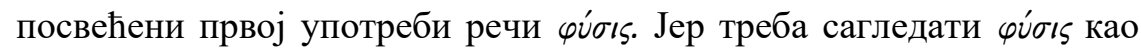
бити које је увек већ у бивању, као биће које јесте у догађању. Другим речима, нећемо код Хомера пронаћи хероја мимо херојског чина у догађају, догађај мимо божанског дејства, снагу мимо покрета. Ничеански речено нема субјекта иза, који стоји мимо самог чина. ${ }^{37}$ Тако песници готово никад не говоре о чv́бı-у у општем, апстрактном, апсолутном смислу мимо његове уприсутности у бивању бића, па и када је реч о уприсутним својствима рода бића. На крају песници не говоре ни о શ⿻іор-у као таквом. ${ }^{38}$ Треба, дакле, основу фv- сагледати мимо навикнутости мишљења на дистинкцију бивања и бивствовања. Јер основа $\varphi$ - још сабира оно што ми називамо или бивање или бивствовање. ${ }^{39}$ Она је у целини наш глагол јесте.

\section{HOM. OD. Х 302-306: PHYSIS У ДОГАЂАЈУ}

Прву забележену употребу речи чv́бı треба посматрати у ширем контексту догађаја у којој се она појављује, јер из њега израња смисао који и сама реч носи.

Лепокоса богиња Кирка, божанску певајући песму, намами Одисејеве сапутнике у своје дворе, те их напитком од „погубних“

ranih grčkih filozofa, Službeni glasnik, Beograd, 2007. Хејдел је учинио први

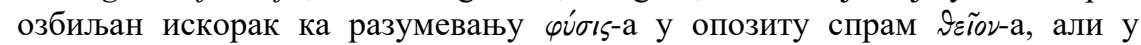
спрези са митским начином мишљења, чини се, међутим, да истраживачи који су следили његове резултате нису у потпуности то препознали. Видети у: Heidel, W., А., "Пє among the Pre-Socratics".

${ }^{37}$ Tatalović, N., „Niče i problem 'metafizike”, u Velikani filozofskih nauka, knj. 4, Univerzitetska biblioteka Svetozar Marković, Beograd, 2018/19, str. 113123 , str. 117.

${ }^{38}$ Изузетак је Еурипид и стихови из његове изгубљење Оде, које Барнет истиче како би одбранио свој став да фи́бı носи семантику бића. Видети: Eur. Dramatic Fr. 910.

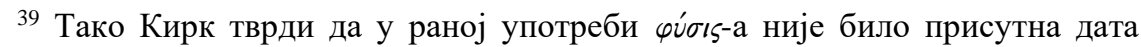
дистинкција. Видети у: Kirk, Heraclitus: The Cosmic Fragments, p. 228. 
трава претвори у крмке. На путу ка богињи, Одисеја сусретне скоротеча, златошапник, пратилац душа у подземни свет, Хермија. Бог Хермија, сличан „младићу најлепше доби“, обраћа се хероју епа Одисеју. Зашто? Да би га ослободио од зла. Хермија одговара упркос томе што питање није изговорено. Заправо, Одисеј не говори, говори једино Хермија. „Погубне“ траве су одређене као зло. Можда, јер њихово дејство нарушава одлике људскости. Наиме, по испијању напитка Одисејеви другови су прво заборавили „очинску земљу“, потом су изгубили људско обличје. Хермија, у сврху ослобађања Одисеја од зла, пружа добру траву и подучава Одисеја исправном опхођењу према богињи. Песник изнова говори о трави, али не више кроз бога Хермију, већ кроз Одисеја:

Hom. Od. X 302-306

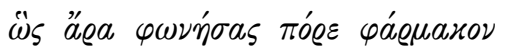

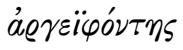

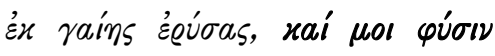

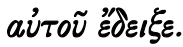

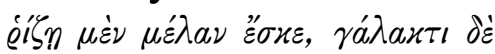

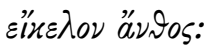

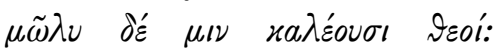

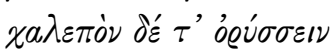

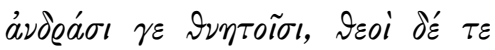

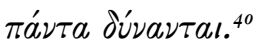

Tako skoroteča reče i onu dade mi travu

Izvadiv je iz zemlje i narav mi pokaza njenu,

Korijen bješe joj crn, cvijetom nalik na mlijeko.

Bozi zovu je moly, a smrtnim ljudima nju je

Teško iskopati gdje, ali bozima sve je moguće. ${ }^{41}$

Потом се Хермија вратио на Олимп, а Одисеј упутио у дворе богиње Кирке, крај које је, заштићен од њених враџбина чи́бı-ом биљке, провео годину дана. Богиња је на молбу Одисеја вратила Одисејевим друговима људско обличје, сада снажније и лепше, и они су га одмах препознали.

${ }^{40}$ Homer, Odyssey X 302-306.

Преузето са сајта: http://www.perseus.tufts.edu/hopper/text?doc=Perseus:text: 1999.01.0135

${ }^{41}$ Homer, Ilijada i Odiseja, prev. T. Maretić, Matica hrvatska, Zagreb, 1961, str. 720 . 
Следе разине на којима се показују одређења изворног

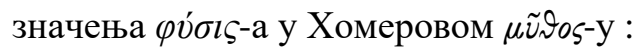

1. Козмо-теогонијска хрид

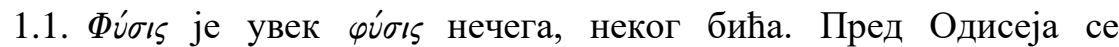

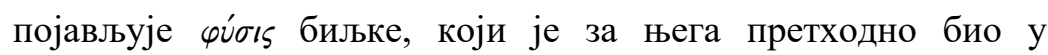
потпуности непознат. И не само да је ф́́бı непознат, већ је и сама биљка тиме од смртника скривена (Hom. Od. X 302).

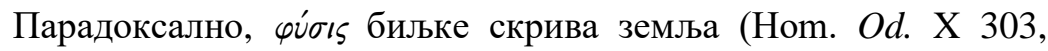
$306)$, при чему биљка сама израња из ње, као из онога одакле је њено ницање и њено израстање. Земља је, као скривено присуство ч́́бı-а, скривено присуство ницања.

1.2. Али, уколико Хермија подучава ${ }^{42}$ Одисеја ницању биљке, то није тек спољашња промена на биљци, већ пре начело ницања, оно чиме биљка јесте у ницању. Речју, чи́бı означава: уприсутно начело ницања, израстања, раста и узрастьа;

1.3. При предочавању чv́бı -а искрсава спољашњи изглед биљке, наиме боја њеног корена и цвета. У појави биљке присуствује

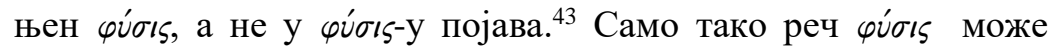
означавати појаву;

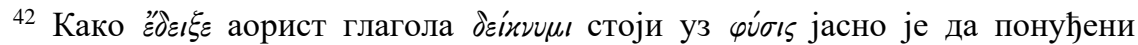

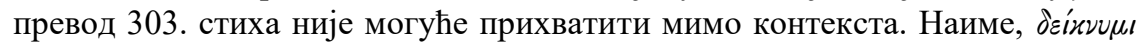
значи изнети на видело, показати, али такође и подучити (некога нечему), при чему је извесно да је Хермија подучио Одисеја о својствености биљке непознате смртницима, која се огледа у дејству које има над чаролијама.

43 Лавџој сугерише значење речи чv́vাร-а код Хомера као квалитативног карактера или дотераности (make-up), што је блиско спољашњем изгледу. Међутим, како видимо, није реч о потпуном подударању значења, јер ипак је код Хомера чv́бı много шире од онога што нуди реч настанак или телесни раст, а његово the dominant and central sense, apparently even so early as Homer, and certainly in fifth century writers, involves the idea of 'qualitative character,' 'make-up,' 'essential nature'. ${ }^{43}$ Lovejoy, O., „The Meaning of Фvбıs in the Greek Physiologers“, p. 376. 
2. Логосно-виталистичка хрид

2.1. Фं́бı се смртнику појављује у близини божанског. Заправо, смртнику се отвара тек након интервенције неког од богова, у овом случају Хермије. За смртника чи́бı није, не постоји, мимо његовог односа са божанском природом. Зашто? Јер се слично сличним спознаје, и како у козмо-теогонијском

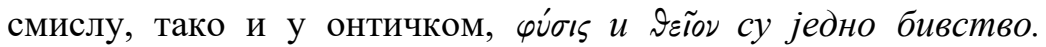
Смртнику је немогуће да га позна својом смртношћу (Hom. Od. X, 305, 306);

2.2. Боговима чv́бı није откривен, већ је за божанско и божанским

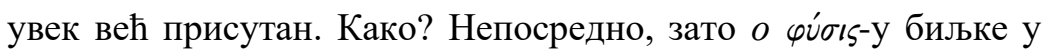
епу и не проговара Хермија, већ је на-зива и пружа је

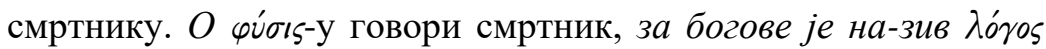
(сабиралиште, говор) самог чи́бı-а. Одатле треба разумети и обредну функцију речи у култовима, у митском. У њима је назив такође при-суство божанског, не само и тек реч, не било која реч. На-зив је при-зив и при-суство, ${ }^{44}$

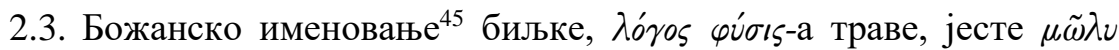
(Hom. Od. X 305). Називом је Хермија саопштио дејство, делотворност биљке Одисеју, јер $\mu \tilde{\omega} \lambda v$ највероватније према етимолошком корену значи оно што поништава магијске

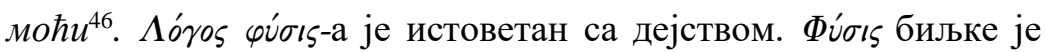
њена снага која је узрок обрта у догађању, како то говори само име биљке.

\footnotetext{
44 По-казивање (које је овде једнако са подучавањем) је начин откривања присуства смртнику. Зато у стиховима стоји, са једне стране божанско

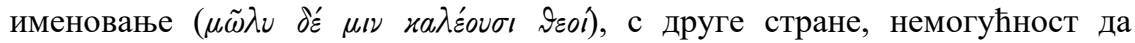

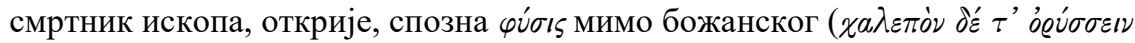

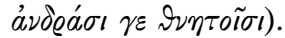

${ }^{45} \mathrm{O}$ нивоима изричаја, о разлици између божанског и људског именовања, видети у: Miljević, A., Kaluđerović, Ž., „Filozofska osnova Parmenidova stiha“, u: Filozofska istraživanja, 147, 2017, str. 597-613.

${ }^{46}$ Homer, Ilijada i Odiseja, prev. T. Maretić, str. 720.
} 
3. Етосно-вредносна хрид

3.1. Да бисмо докучили нијансирање значења чv́бıљ-а које следи, морамо се вратити три корака уназад, наиме на тачку 2.1. којом се намеће питање: ако смртник не спознаје чи́бı својом

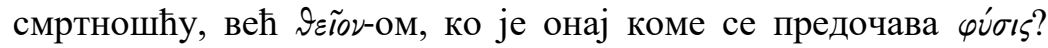
Фúбৎ се открива Одисеју, са-учеснику у божанском догађању, који сваким својим чином потврђује херојску изврсност. Његова самосвојност није статична, није издвојена из догађаја. Она се изграђује, расте, начином на који Одисеј јесте у догађају. Изврсност још означава племенитост и снагу којом смртник са-учествује у божанском. Изведено, изврсношћу се

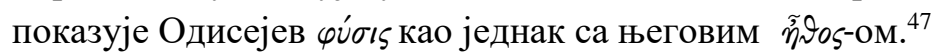

3.2. Одатле дејство $\mu \tilde{\omega} \lambda \nu$ чува Одисејев племенити чи́бı од враџбина које могу паралелно да промене његову

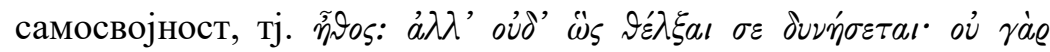

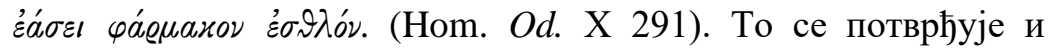
претходним стиховима у којима су Одисејеви другови

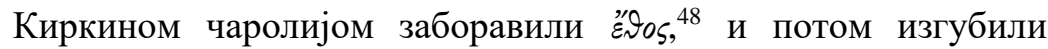

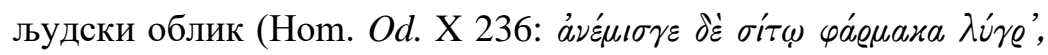

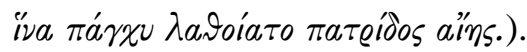

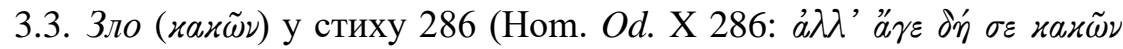

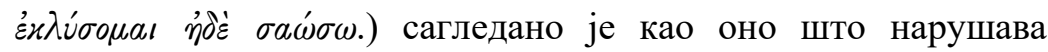

${ }^{47}$ Песници су користили у овом смислу именицу чи' исте основе као и реч

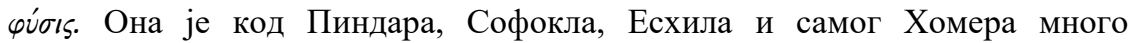
фреквентнија од речи чи́бıs. Према Бирдслију, на небројано много места каже се једноставно чи'́ када се истиче врлинска изврсност јунака, што

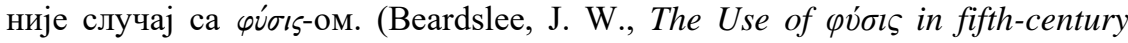
Greek Literature, p. 7.) Са Бирдслијем се слаже Мајрес, али он при том инсистира на процесуалном значењу речи, тј. да две одлике, физичке карактеристике биљке које су наведене, означавају два начина њеног појављивања, у лето и зиму, а чи́бı биљке означава целину процеса раста и развоја. Видети у: Myres, J., The Political Ideas of Greeks, The Abingdon Press, New York, 1927, pp. 255-257. Синонимна употреба ове две речи је такође честа, а временом је чv́бı преузео значења која је носила именица

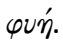

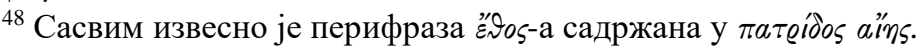




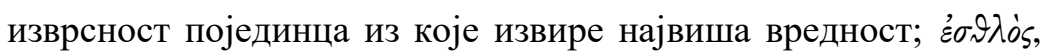
добро, је отворено кроз фи́б биљке у следећем стиху (Hom.

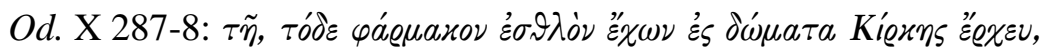

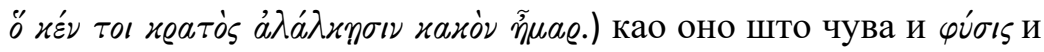

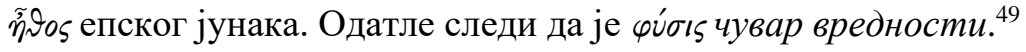

На концу догађаја, Одисејевим друговима богиња Кирка враћа сећање и људско обличје, заслугом самог Одисеја и његовог врлинског држања. Епски јунак обнавља заједницу (عُحоs) својом

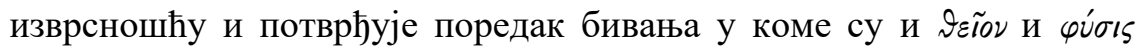
једно бивство.

\section{ЛИТЕРАТУРА}

Aristotel, Metafizika, prev. Ladan, T., Globus, Zagreb, 1988.

Aristotel, Metafizika, prev. Blagojević, S., Paideia, Beograd, 2010.

Aristotle, Metaphysics. Преузето са cajтa: http://www.perseus.tufts.edu/ hopper/text?doc=Perseus\%3atext\%3a1999.01.0051

Aristotle, Protreptikos. Преузето ca cajтa: http://www.protrepticus.info/

Barnet, Dž., Rana grčka filozofija, prev. B. Gligorić, Zavod za udžbenike i nastavna sredstva, Beograd, 2004.

Beardslee, J. W., The Use of $\varphi v \sigma \iota \varsigma$ in fifth-century Greek Literature, The University of Chicago Press, Chicago, 1918.

Frisk, H., Griechische ethymologische Wörterbuch, Band II, Heidelberg, 1970.

Gorski, O., Majnarić, N., Grčko-hrvatski ili srpski rječnik, Školska knjiga, Zagreb, 1983.

Graham, D. W, „Does Nature Love to Hide? Heraclitus B123 DK“, in: Classical Philology, 98, 2003., pp. 175-179.

Guthrie, W. K. C, „The Presocratic World-Picture” in: The Harvard Theological Review, Vol. 45, 1952, pp. 87- 104.

\footnotetext{
49 У том смислу Калуђеровић с правом истиче да је хеленско поимање

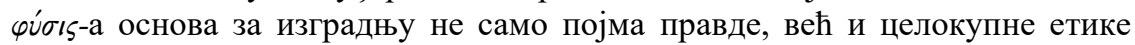
хеленског човека: $U$ tom preuzimanju pojam physis će postati relevantan $i$ merodavan za adekvatno razumevanje onoga što Aristotel prikladno zove "ljudske stvari". Jednom izražena ova ideja postala je zajednička svojina klasičnog misaonog diskursa. Kaluđerović, Ž., Helensko poimanje pravde, Izdavačka knjižarnica Zorana Stojanovića, Sremski Karlovci/Novi Sad, 2010, str. 45 .
} 
Hardy, E., Der Begriff der Physis in der Griechischen Philosophie, Erster Teil, Weidmannsche Buchhandlung, Berlin, 1884.

Heidegger, M., Einführung in die Metaphysik, Vittorio Klostermann, Frankfurt am Main, 1983.

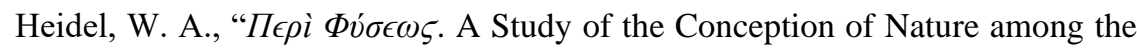
Pre-Socratics" in Proceedings of the American Academy of Arts and Sciences, Vol. 45, 1910.

Holwerda, D., Commentatio de vocis quae est $\Phi Y \Sigma I \Sigma$ VI atque usu praesertim in graecitate Aristotele anteriore, Groningen, 1955.

Homer, Ilijada i Odiseja, prev. T. Maretić, Matica hrvatska, Zagreb, 1961.

Homer, Odyssey, преузето са сајта: http://www.perseus.tufts.edu/ hopper/text?doc=Perseus:text:1999.01.0135

Jeger, V., Teologija ranih grčkih filozofa, Službeni glasnik, Beograd, 2007.

Kaluđerović, Ž., Helensko poimanje pravde, Izdavačka knjižarnica Zorana Stojanovića, Sremski Karlovci/Novi Sad, 2010.

Kirk, Heraclitus. The Cosmic Fragments, Cambridge University Press, London/New York,1954.

Liddell, H. G., Scott, R., An Intermediate Greek-English Lexicon. Преузето са сајта:

http://www.perseus.tufts.edu/hopper/text?doc=Perseus\%3Atext\%3A19

99.04.0058\%3Aentry\%3Dfu\%2Fsis

Lovejoy, O., „The Meaning of $\Phi v \sigma i \varsigma$ in the Greek Physiologers“, in: The Philosophical Review, Vol. 18, 1909, pp. 369-383.

Miljević, A., „Određenje životne snage u Homerovim epovima”, u: Godišnjak Filozofskog fakulteta u Novom Sadu, 42, 2017., 47-58.

Miljević, A., „Physis u filozofiji Milećana”, u Arhe, 30 , 2018, str. 213-229.

Miljević, A., Kaluđerović, Ž., „Filozofska osnova Parmenidova stiha“, u: Filozofska istraživanja, , 147, 2017, str. 597-613.

Myres, J., The Political Ideas of Greeks, The Abingdon Press, New York, 1927.

Patzer, H., Physis: Grundlegung zu einer Geschichte des Wortes, Steiner, Wiesbaden, 1993.

Steinthal, H., Geschichte der Sprachwissenschaft bei den Griechen und Römer, mit besonderer Rücksicht auf die Logik, Ferd. Dümmler`s Verlagsbuchhandlung, Berlin, 1883.

Tatalović, N., „Niče i problem 'metafizike””, u Velikani filozofskih nauka, knj. 4, Univerzitetska biblioteka Svetozar Marković, Beograd, 2018/19, str. 113-123. 


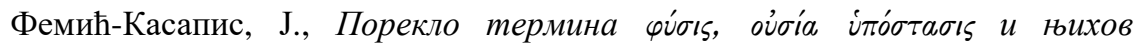
семантички развој од најранијих помена до црквених отаца, ПБФ, Београд, 2010. 


\author{
ANA MILJEVIĆ \\ University of Novi Sad, Faculty of Philosophy
}

\title{
DETERMINATIONS OF THE ORIGINAL MEANING OF PHYSIS AS A PROBLEM OF ONTOLOGY
}

\begin{abstract}
The question of the original meaning of qúoıs is asked for the sake of our own ontological positioning, for the sake of the modernity in which and with which we significantly are. This paper therefore examines the semantics of the root $\varphi v \sigma^{\prime} \iota$, the Hellenic basis $\varphi v$-, and hence the possible connection with

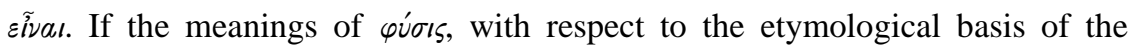
word, lie between growth and being, then the question of the layering of meaning in its poetry usage arises. The paper examines the given ambiguity through the relationship of $2 \varepsilon \tilde{i} \nu \nu$ and $\varphi \dot{v} \sigma \varsigma$. There are three moments of this relationship that are present in mythical thinking: cosmo-theogonic, logosvitality and ethos-value. The thesis is that from these rocks the mythical yúr/s can be seen in its original meaning as an event by which the being is. This thesis is examined on the example of the meaning of yvoıs in Homer's Odyssey.
\end{abstract}

Keywords: physis, ontology, mythology, semantics, Homer

Primljeno: 31.8.2021.

Prihvaćeno: 2.11.2021. 
